\title{
ÉTUDE DES EFFETS DES TRAITEMENTS TECHNOLOGIQUES DE L'AMIDON PAR ANALYSE des CONTENus digestifs CHEZ Le PORC
}

\author{
J. DELORT-LAVAL, L.-P. BORGIDA, Geneviève CHARLET-LERY et S.-Z. ZELTER \\ Laboratoire de Recherches sur la Conservation et l'Efficacité des Aliments, \\ Centre national de Recherches zootechniques, I. N.R.A., \\ 78 - Jouy-en-Josas
}

L'analyse des contenus digestifs de porcs abattus après un repas d'épreuve, complète et précise: l'information fournie par le bilan de la matière sèche et de ses composants.

Io En présence de fécule de pomme de terre crue, l'utilisation de la matière sèche et organique du régime est médiocre. Dans l'estomac d'animaux abattus trois heures après le repas, l'amidon cru est peu dégradé (6-8 p. Ioo vs $72-78$ p. I00 pour la fécule cuite) ; leur gros intestin contient nettement plus de matière sèche $(+59$ p. roo) et d'azote $(+54$ p. roo).

La prolongation du jeûne azoté réduit l'utilisation du régime à base de fécule crue : l'activité amylasique des fèces d'animaux qui en ingèrent, d'abord élevée, s'affaiblit ensuite, tandis qu'une part croissante de l'amidon ingéré est excrétée dans les fèces, qui en contiennent 6 p. roo après. r6 jours et $2 \mathrm{I}$ p. Ioo après 26 jours de régime protéiprive.

$2^{\circ}$ Le maïs immature (épi + spathes) peut être conservé par déshydratation ou ensilage. Sous cette dernière forme, l'utilisation digestive des composants de la matière sèche s'avère meilleure. Corrélativement on observe avec la céréale ensilée :

a) un ralentissement du transit intestinal,

b) une activité amylolytique notable au niveau stomacal, mais réduite dans l'intestin grêle par rapport au maïs déshydraté,

c) un taux de dégradation de l'amidon toujours plus élevé : on retrouve une heure après le repas 26,4 p. Ioo de l'amidon ingéré dans l'estomac, o,6 dans l'intestin grêle et o, I dans le gros intestin avec l'ensilage contre respectivement $65-3,5-9,5$ pour le produit déshydraté.

\section{SUMMARY}

STUDY ON THE EFFECT OF SOME TECHNOLOGICAL TREATMENTS OF STARCH BY ANALYSIS OF THE DIGESTIVE TRAC'T CONTENTS OF THE GROWING PIG

By analysis of the digestive tract contents of pigs slaughtered after a test meal, an accurate information is added to the data of the dry matter digestibility and that of its components.

$I^{0}$ In presence of raw potato starch, the utilization of the dry matter and organic matter of the diet is poor. In the stomach of animals slaughtered three hours after the meal, the raw starch is only slightly hydrolyzed (6-8 p. 100 vs $72-78 \mathrm{p}$. 100 for cooked potato starch); in their large intestine, there is much more dry matter $(+59 \mathrm{p}$. Ioo) and nitrogen $(+54 \mathrm{p}$. Ioo).

After a longer protein depletion the utilization of the diet containing raw potato starch is reduced : the amylase activity in the faeces of animals fed this diet is initially high and then 
decreases, whereas an increasing part of the ingested starch $(6 \mathrm{p}$. Ioo after I6 days and $2 \mathrm{I}$ p. Ioo after 26 days of $\mathrm{N}$-free diet) is excreted in the faeces.

$2^{\circ}$ Immature (50 p. roo DM) maize (corn and cobs) may be dehydrated or ensiled. Under this last form, the digestibility of the components of the dry matter is higher and, correlatively, the following facts are observed :

a) decrease of the intestinal transit rate,

b) important amylolytic activity in the stomach but reduced in the small intestine, in comparison with that observed on the dehydrated maize diet,

c) an always higher rate of amylolysis : one hour after the silage meal, 26.4 (expressed as p. Ioo of the ingested starch) are recovered in the stomach, 0.6 in the small intestine and 0.1 in the large intestine, vs $65 \cdot 0-3.5-9.5$ respectively for the dehydrated product.

\title{
UTILISATION DIGESTIVE DES ACIDES GRAS
}

\author{
J. FLANZY \\ Station de Recherches de Nutrition, \\ Centre national de Recherches zootechniques, I. N. R. A., \\ 78 - Jouy-en-Josas
}

La digestibilité des acides gras ingérés sous forme de triglycérides mixtes a été étudiée chez le Porc. Les CUD moyens apparents obtenus sont les suivants : acide laurique, 90 p. Ioo ; acide myristique, 67 p. roo ; acide palmitique, 46 p. roo; acide stéarique, $4^{\circ}$ p. Ioo; acide oléique, 90 p. 100 ; acide linoléique, 95 p. Ioo.

La faible digestibilité de certaines graisses est liée à une augmentation de la proportion de composés insolubles retrouvée dans les fèces. Ces composés insolubles, vraisemblablement des sels de $\mathrm{Ca}^{++}$, se formeraient au cours de la digestion, dans la lumière intestinale, surtout à partir des acides saturés, palmitique et stéarique.

L'influence de la structure glycéridique a été étudiée : en effet, quand l'acide palmitique est en position $\beta$ dans la molécule de triglycéride (cas du saindoux), il est absorbé sous forme de $\beta$-monoglycéride. Son CUD apparent est alors de $86 \mathrm{p}$. гоo.

Chez le Rat, on a mis en évidence une compétition entre acides gras et acide phosphorique pour la formation des savons de calcium.

Par l'emploi d'animaux axéniques, on a montré l'influence de la flore intestinale sur la digestibilité des acides gras. Le CUD des acides palmitique et stéarique est plus faible dans le cas des animaux holoxéniques que dans celui des animaux axéniques. L'hydrogénation des acides insaturés par la flore intestinale est quantitativement négligeable.

\section{SUMMARY}

\section{DIGESTIVE UTILIZATION OF FATTY ACIDS}

Digestibility of fatty acids ingested in the form of mixed triglycerides was studied in pigs. The apparent mean digestibilities obtained were as follows : lauric acid 90 p. Ioo, myristic acid 67 p. I0o, palmitic acid 46 p. 100, stearic acid 40 p. Ioo, oleic acid 90 p. Ioo and linoleic acid 95 p. זоo. 